\title{
AKURASI
}

p-ISSN : 2720-9067

e-ISSN : 2685-1059

Program Studi Magister Akuntansi

Fakultas Ekonomi dan Bisnis

Universitas Mataram

\section{PERBANDINGAN PERLAKUAN AKUNTANSI ASET BIOLOGIS BERDASARKAN PSAK 16 DAN PSAK 69 PADA PERUSAHAAN AGRIKULTUR}

\author{
Argie Destri Rahmani ${ }^{1}$, I Gusti Ketut Agung Ulupui ${ }^{2}$, Dwi Handarini ${ }^{3}$, Hafifah Nasution ${ }^{4}$ \\ Universitas Negeri Jakarta, Indonesia ${ }^{1234}$ \\ ${ }^{1234}$ Corresponding author: igka-ulupui@unj.ac.id iD https://orcid.org/0000-0002-0549-4148
}

\section{INFORMASI ARTIKEL}

Article history:

Dikirim: 20/03/2021

Revisi pertama: $29 / 04 / 2021$

Diterima: 25/05/2021

Tersedia online: $21 / 06 / 2021$

\begin{abstract}
ABSTRAK
Penelitian ini mendeskripsikan perbedaan perlakuan akuntansi aset biologis pada perusahaan agrikultur sebelum dan sesudah penerapan PSAK 69. Analisis deskriptif komparatif dan interaktif digunakan pada 15 perusahaan agrikultur terdaftar di Bursa Efek Indonesia tahun 2017-2018. Hasil studi ini menunjukkan bahwa berdasarkan PSAK 16, perusahaan agrikultur mengakui tanaman perkebunan sebagai aset dan tidak mengakui produk agrikultur sebagai aset biologis, sedangkan berdasarkan PSAK 69 perusahaan agrikultur tidak mengakui tanaman perkebunan sebagai aset biologis, melainkan sebagai aset tetap. Aset biologis yang diakui oleh perusahaan agrikultur berupa produk agrikultur, tanaman semusim, dan hewan. Aset biologis berdasarkan PSAK 16 diukur menggunakan biaya perolehan dengan rincian biaya kapitalisasi yang berbeda-beda tiap perusahaannya dan aset biologis mengalami penyusutan, namun berdasarkan PSAK 69 pengukurannya menggunakan nilai wajar dikurangi biaya untuk menjual dan aset biologis tidak disusutkan. Berdasarkan PSAK 16, perusahaan agrikultur mengungkapkan hal-hal terkait penyusutan, sedangkan berdasarkan PSAK 69, mengungkapkan deskripsi kelompok aset biologis dan nilai keuntungan/kerugian yang timbul akibat penggunaan nilai wajar. Studi ini juga mengungkapkan 3 dari 15 perusahaan agrikultur yang terdaftar di Bursa Efek Indonesia periode 2018 telah menerapkan PSAK 69 secara penuh, sedangkan 12 perusahaan lainnya menerapkan PSAK 69 sebanyak 50\% hingga 94\%.
\end{abstract}

Kata Kunci: Aset biologis, perlakuan akuntansi, PSAK 16, PSAK 69.

\begin{abstract}
This study describes the differences in the accounting treatment of biological assets in agricultural companies before and after implementing the statement of Financial Accounting Standard (FAS) 69. Comparative and interactive descriptive analysis was used on 15 agricultural companies listed on the Indonesia Stock Exchange 2017-2018. This study indicates that agricultural companies recognize plantation crops as assets based on FAS and do not recognize agricultural products as biological assets. In contrast, FAS 69 agricultural companies do not recognize plantation crops as biological assets but fixed assets. Biological assets recognized by agricultural companies are agricultural products, seasonal crops, and animals. Biological assets based on FAS 16 are measured at cost with details of capitalization costs that vary by company, and biological assets are depreciated. However, based on FAS 69, the measurement uses fair value fewer costs to sell, and biological assets are not depreciated. In addition, based on FAS 16, agricultural companies disclose matters related to depreciation. Based on FAS 69, they disclose descriptions of biological assets and the value of gains/losses arising from the use of fair value. This study reveals that 3 of the 15 agricultural companies listed on the Indonesia Stock Exchange for the 2018 have fully implemented FAS 69, while 12 companies have implemented it around 50\% to $94 \%$.
\end{abstract}

Keywords: Accounting treatment, biological assets, FAS 16, FAS 69 


\section{DOI: 10.29303/akurasi.v4i1.84}

Open access under Creative Commons Attribution-ShareAlike 4.0 International License.

\section{(CC-BY-SA)}

\section{Pendahuluan}

Indonesia disebut sebagai negara agraris tropis terbesar kedua setelah Brazil (Gischa, 2019). Indonesia dikaruniai hutan hujan tropis yang relatif luas jika dibandingkan dengan negara lain. Hal tersebut menjadikan Indonesia memiliki keberagaman flora dan fauna yang tinggi di dunia (indonesia.go.id, 2018). Berbagai jenis tumbuhan dapat tumbuh dengan subur di Indonesia. Kekayaan flora dan fauna ini dapat dimanfaatkan oleh masyarakat sebagai sumber daya untuk menghasilkan keuntungan. Pemanfaatan flora dan fauna dalam kegiatan bisnis dikenal dengan bisnis sektor agrikultur. Sektor agrikultur berperan penting dalam pertumbuhan perekonomian nasional. Dalam bursa perdagangan saham di Indonesia, sektor agrikultur dibedakan dalam enam subsektor, yaitu tanaman pangan (crops), perkebunan (plantation), peternakan (animal husbandry), perikanan (fishery), kehutanan (forestry), dan lainnya (others). Jumlah perusahaan agrikultur yang terdaftar di Bursa Efek Indonesia hingga akhir tahun 2019 mencapai 21 perusahaan (IDX, 2019). Sektor agrikultur ini merupakan sektor yang sangat menjanjikan, sehingga banyak investor yang melirik sektor ini (Syukra, 2019). Meskipun demikian, untuk meningkatkan potensi sektor ini, diperlukan investasi berkelanjutan.

Salah satu cara yang dapat dilakukan untuk meningkatkan investasi di pasar modal yaitu dengan menyajikan laporan keuangan yang relevan dan andal, tidak terkecuali pada perusahaan agrikultur. Hal ini dikarenakan investor memiliki pandangan bahwa laporan keuangan berkualitas tinggi memiliki kemampuan untuk dibandingkan dengan perusahaanperusahaan lainnya. Untuk meningkatkan daya banding laporan keuangan, Indonesia melalui Dewan Standar Akuntansi Keuangan Ikatan Akuntan Indonesia (DSAK IAI) melakukan konvergensi International Financial Reporting Standard (IFRS) sejak tahun 2008 dan diimplementasikan secara bertahap hingga tahun 2012. Penggunaan standar akuntansi internasional dapat memungkinkan untuk membandingkan laporan keuangan secara global, meningkatkan transparansi dalam pelaporan keuangan, mengurangi biaya informasi, dan mengurangi informasi yang tidak simetris (Ball, 2006 dalam Ariyanto et al., 2014). Penggunaan standar akuntansi internasional harus mencakup seluruh sektor usaha, tidak terkecuali sektor agrikultur. Standar akuntansi internasional untuk sektor agrikultur ialah International Accounting Standard (IAS) 41 yang terbit di akhir tahun 2000 (Feleaga et al., 2012). IAS 41 menuai kontroversi dari berbagai pihak karena dinilai belum sesuai dengan karakteristik sektor agrikultur (Ariyanto et al., 2014), meskipun beberapa negara, terutama negara-negara maju telah menggunakan standar tersebut. Hal ini dikarenakan sektor agrikultur bukan merupakan sektor utama yang memengaruhi perekonomian negaranya. Berbeda dengan negara berkembang, seperti Indonesia dan Malaysia yang masih sulit untuk mengimplementasikan IAS 41 (Saputra \& Kurniawan, n.d.). IAS 41 yang mengatur perlakuan akuntansi untuk aset biologis menimbulkan banyak kontroversi mengenai pengukurannya yang didasarkan pada nilai wajar. Sebelum dikeluarkan IAS 41, pengukuran aset biologis dihitung berdasarkan biaya perolehannya. Setelah mendapat 
banyak kritik, akhirnya terbitlah amandemen IAS 41 yang isinya memisahkan bearer plants dari ruang lingkup IAS 41. Hal ini dilakukan karena bearer plants lebih memenuhi kriteria aset tetap.

Sampai dengan tahun 2014, Indonesia belum memiliki standar yang mengatur mengenai agrikultur. DSAK IAI masih belum melakukan adopsi IAS 41 karena menunggu amandemen IAS 41. Setelah dikeluarkannya amandemen IAS 41, barulah DSAK IAI melakukan adopsi IAS 41 ke dalam Pernyataan Standar Akuntansi Keuangan (PSAK). Hasil adopsi tersebut ialah PSAK 69 Agrikultur yang berlaku efektif per 1 Januari 2018. PSAK 69 mengatur perlakuan akuntansi untuk hal-hal yang berkaitan dengan aktivitas agrikultur, termasuk aset biologis. Dalam IAS 41, aset biologis didefinisikan sebagai "living plants or animals" (Deloitte, n.d.). Hewan atau tumbuhan memiliki karakteristik yang unik dibanding jenis aset lain, yaitu adanya transformasi biologis. Transformasi biologis merupakan proses perubahan kuantitatif atau kualitatif yang terjadi pada hewan dan tumbuhan. Sebelum diberlakukannya PSAK 69, perlakuan akuntansi untuk aset biologis di Indonesia menggunakan pedoman PSAK 16 Aset Tetap. Perbedaan yang paling mendasar adalah pada aspek pengukurannya. Pengukuran aset biologis pada PSAK 16 didasarkan pada biaya perolehan aset tersebut, sedangkan PSAK 69 mengukur aset biologis berdasarkan nilai wajar dikurangi biaya untuk menjual.

Perbedaan perlakuan akuntansi untuk aset biologis tidak hanya pada pengukurannya saja, tetapi juga pada pengakuan, penyajian, dan pengungkapannya. Studi empiris tentang perlakuan akuntansi untuk aset biologis pada perusahaan agrikultur masih memberikan bukti yang relatif terbatas. Kodriyah \& Monica (2018) dengan menggunakan pendekatan deskriptif kualitatif memberikan gambaran mengenai analisis perbedaan perlakuan akuntansi aset biologis pada perusahaan perkebunan di Indonesia berdasarkan IAS 41 Agriculture dan PSAK 16 Aset Tetap. Hasil penelitiannya menyatakan bahwa sebanyak 15 dari 16 sampel perusahaan perkebunan masih menggunakan metode biaya dalam pengukurannya, yang dianggap dapat menghasilkan laporan keuangan yang tidak relevan (distorsi akuntansi). Dalam aspek penyajian, terdapat perbedaan yang signifikan antara IAS 41 dan PSAK 16. IAS 41 tidak mengakui adanya akumulasi depresiasi pada pencatatan aset biologisnya, sedangkan PSAK 16 mengakui adanya akumulasi depresiasi sehingga perbedaan tersebut menyebabkan perbedaan nilai pada laporan laba rugi. Studi lainnya dilakukan Hariyanti \& Wijayanti (2018) yang menganalisis perbandingan perlakuan akuntansi aset biologis berdasarkan International Accounting Standard 41 dan Pernyataan Standar Akuntansi Keuangan 69 pada perusahaan perkebunan yang terdaftar di Bursa Efek Indonesia. Hasil penelitian tersebut menyimpulkan bahwa perbandingan akuntansi aset biologis antara praktik di perusahaan dengan IAS 41 menunjukkan ketidaksesuaian karena praktik perlakuan akuntansi aset biologis berdasarkan IAS 41 belum sepenuhnya diadopsi oleh perusahaan. Perlakuan akuntansi aset biologis pada praktik di perusahaan perkebunan tidak sesuai dengan PSAK 69 karena masih banyak perusahaan perkebunan yang belum menerapkan PSAK 69 secara utuh.

Penelitian ini bertujuan memberikan bukti baru dengan mendeskripsikan tentang perbedaan perlakuan akuntansi aset biologis sebelum dan sesudah penerapan PSAK 69, yaitu berdasarkan PSAK 16 dan PSAK 69 pada perusahaan agrikultur terdaftar di Bursa Efek Indonesia pada tahun 2017-2018. Fokus penelitian dilakukan terhadap perbedaan 
perlakuan akuntansi yang berkaitan dengan pengakuan, pengukuran dan penyajian aset biologis dalam perusahaan agrikultur. Hasil penelitian ini memberikan gambaran tentang adopsi standar perlakuan akuntansi untuk aset biologis dalam praktik di perusahaan agrikultur terdaftar di Bursa Efek Indonesia dengan menggunakan PSAK 16 dan PSAK 69. Dalam aspek regulasi hasil penelitian ini dapat memberikan masukan untuk penyempurnaan standar akuntansi yang berkaitan pengakuan, pengukuran dan pengungkapan aset biologis pada perusahaan agrikultur.

\section{Kerangka Teoretis}

Teori regulasi mengargumentasikan perekonomian terpusat adalah alasan dalam melindungi kepentingan umum. Dalam teori ini legislatif membuat aturan untuk melindungi pengguna laporan keuangan dengan meningkatkan kinerja ekonomi. IFRS sebagai standar akuntansi yang baru juga ditujukan untuk menciptakan suatu regulasi yang dapat memenuhi semua kebutuhan setiap pengguna sehingga kebijakan akuntansi baru (IFRS) mengakibatkan perubahan dalam standar dan memengaruhi baik rasio keuangan maupun angka keuangan dari setiap aktivitas keuangan dan memengaruhi informasi akuntansi secara keseluruhan (Suhartono, 2018). Teori regulasi mengargumentasikan bahwa adanya krisis yang muncul di masyarakat dapat mendorong permintaan terhadap kebijakan atau standar sebagai solusi dari permasalahan tersebut. Pihak pembuat standar memberikan tanggapan dengan cara menyediakan kebijakan tersebut. Regulasi dibuat demi memenuhi kepentingan banyak pihak (Ghozali \& Chairiri, 2007). Teori regulasi digunakan dalam penelitian ini untuk menjustifikasikan adanya standar/ aturan internasional baru mengenai akuntansi agrikultur yang dalam implementasinya menimbulkan kontroversi karena pengukurannya yang didasarkan pada nilai wajar. Padahal sebelumnya pengukuran aset biologis dihitung pada biaya perolehannya. Amandemen IAS 41 adalah bentuk respon regulasi terhadap kritik tersebut yang isinya memisahkan tanaman produktif (bearer plants) dari ruang lingkup IAS 41 karena bearer plants lebih memenuhi kriteria aset tetap.

Pada Desember 2000, IASB mengesahkan International Accounting Standard (IAS) 41 yang mulai berlaku efektif pada 1 Januari 2003.Terbitnya IAS 41 menimbulkan banyak kontroversi. Salah satunya adalah banyaknya anggapan bahwa pendekatan yang digunakan dalam IAS 41 terlalu akademik dan tidak fokus pada pelaporan aset biologis (Herbohn \& Herbohn, 2006 dalam Ariyanto et al., 2014). Dalam menanggapi berbagai kontroversi yang ada, IASB melakukan beberapa perbaikan/amandemen pada IAS 41. Amandemen yang pertama mengenai tingkat diskonto disahkan pada 22 Mei 2008 dan berlaku efektif mulai 1 Januari 2009. Amandemen kedua mengenai bearer plants (tanaman produktif) yang dikecualikan dari ruang lingkup IAS 41 dan kembali ke IAS 16 Property, Plants, and Equipment. Di tahun 2000, Indonesia belum mengadopsi IAS 41 karena standar akuntansi keuangan di Indonesia masih berkiblat pada United States Generally Accepted Accounting Principles (US GAAP). Indonesia baru melakukan adopsi International Financial Reporting Standard (IFRS) pada tahun 2008 - 2012 sebagai komitmen terhadap G-20. IAS 16 Property, Plants, and Equipment diadopsi menjadi Pernyataan Standar Akuntansi Keuangan (PSAK) 16 Aset Tetap pada 29 November 2011. PSAK 16 berlaku efektif di Indonesia pada 1 Januari 2014. Sampai dengan saat itu, aset biologis masih diperlakukan menggunakan PSAK 16. Sebelum 1 Januari 2018, aset biologis di Indonesia masih diatur 
dalam PSAK 16. Hal ini karena IAS 41 belum diadopsi pada konvergensi pertama IFRS tahun 2008-2012. Dewan Standar Akuntansi Keuangan Ikatan Akuntan Indonesia (DSAK IAI) menunda pengadopsian IAS 41 dengan alasan proses amandemen IAS 41 sedang dilaksanakan oleh IASB. Amandemen yang dilakukan merupakan amandemen yang menghasilkan perubahan signifikan, sehingga DSAK IAI memutuskan untuk mengadopsi IAS 41 ke PSAK setelah amandemennya selesai. Ketika amandemen IAS 41 disahkan pada tahun 2014, DSAK IAI membuat regulasi kebijakan untuk menyamakan persepsi akuntansi agrikultur. Dengan demikian regulasi yang dihasilkan ialah PSAK 69 Agrikultur yang merupakan adopsi dari IAS 41.

Aset biologis merupakan tanaman atau hewan yang dimiliki oleh entitas dalam rangka menjalankan usahanya. Menurut IAS 41, aset biologis terdiri dari hewan (animals) dan tanaman (plants). PSAK 69 membagi lagi aset tanaman menjadi tiga jenis, yaitu tanaman produktif (bearer plant), produk agrikultur (growing produce), dan tanaman lainnya sebagimana digambarkan dalam pengelompokan aset biologis pada gambar 1 . Aset biologis merupakan aset yang berbeda dari jenis aset lainnya. Aset biologis dinilai berbeda karena memiliki karakteristik yang tidak dimiliki oleh jenis aset lain. Karakteristik tersebut ialah bahwa aset biologis mengalami transformasi biologis. Transformasi biologis merupakan proses biologis, seperti pertumbuhan (peningkatan ukuran atau jumlah), degenerasi (penurunan kuantitas atau kualitas), produksi, dan prokreasi (penciptaan spesies baru) yang membuat adanya perubahan secara kuantitatif maupun kualitatif pada aset biologis. Transformasi biologis berpengaruh terhadap nilai dari aset biologis tersebut. Transformasi biologis yang dialami aset biologis dapat terjadi secara alami atau dengan bantuan manajemen agrikultur. Manajemen memiliki kemampuan untuk merekayasa kondisi agar transformasi biologis terjadi secara maksimal, sehingga bisa memberikan tambahan nilai untuk perusahaan.

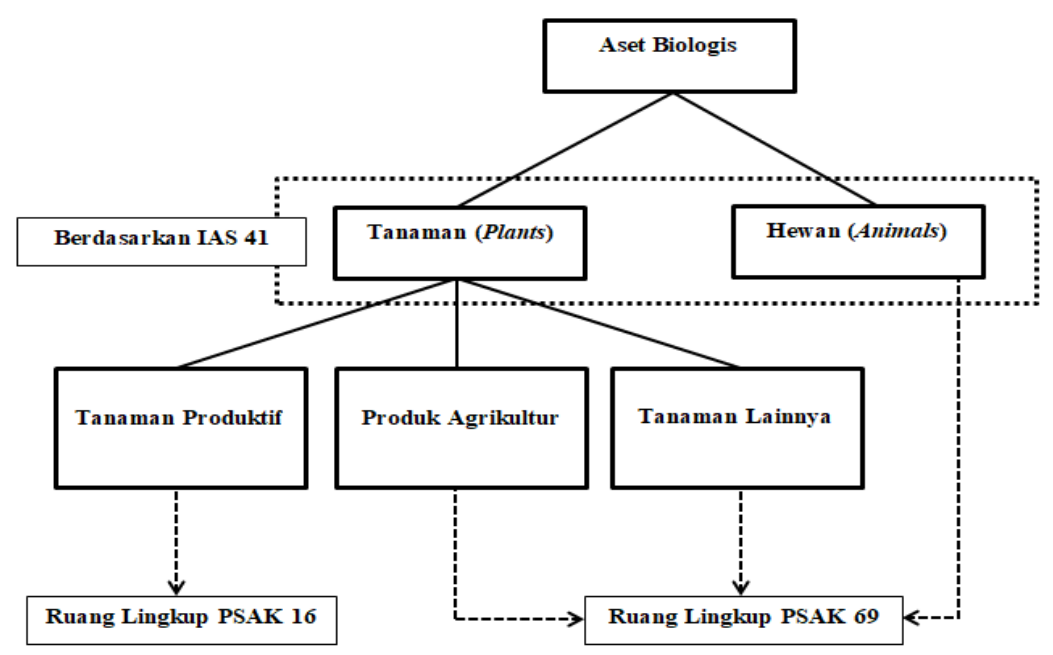

Gambar 1. Pengelompokan Aset Biologis dan Ruang Lingkupnya

PSAK 16 Aset Tetap berlaku untuk setiap aset berwujud yang memenuhi kriteria sebagai aset tetap, kecuali dinyatakan lain oleh PSAK lainnya. Aset tetap merupakan aset berwujud yang dimiliki untuk digunakan dalam proses produksi dan memiliki umur 
manfaat lebih dari satu periode. Menurut amandemen PSAK 16 Aset Tetap tentang Agrikultur: tanaman produktif, tanaman produktif menjadi bagian baru dalam ruang lingkup standar ini. Dalam PSAK 16 Aset Tetap dijelaskan beberapa hal yang tidak masuk dalam ruang lingkup standar ini, yaitu: (a) aset tetap yang diklasifikasi sebagai dimiliki untuk dijual sesuai dengan PSAK 58 Aset Tidak Lancar yang Dikuasai untuk Dijual dan Operasi yang Dihentikan; (b) aset biologis yang terkait dengan aktivitas agrikultur selain tanaman produktif; (c) pengakuan dan pengukuran aset eksplorasi dan evaluasi; serta (d) hak penambangan dan cadangan mineral seperti gas alam, minyak, dan sumber daya serupa yang tidak dapat diperbaharui.

Pengukuran aset tetap dilakukan pada saat pengakuan dan setelah pengakuan. Untuk pengukuran saat pengakuan, aset tetap yang dinilai telah memenuhi kualifikasi pengakuan sebagai aset tetap diukur berdasarkan biaya perolehannya. Biaya perolehan merupakan biaya yang dikeluarkan untuk mendapatkan kuasa atas suatu aset tetap. Pengukuran setelah pengakuan, entitas dapat memilih akan menggunakan metode biaya atau metode revaluasi sesuai dengan kebijakan akuntansinya masing-masing. Metode biaya mencatat aset tetap setelah pengakuan pada biaya perolehan dikurangi akumulasi penyusutan dan akumulasi rugi penurunan nilai. Namun demikian, metode revaluasi diterapkan untuk mencatat aset tetap yang nilai wajarnya dapat diukur secara andal. PSAK 16 Aset Tetap paragraf 43 menyatakan bahwa tiap bagian dari aset tetap yang biaya perolehannya signifikan terhadap total biaya perolehan seluruh aset tetap disusutkan secara terpisah. Entitas dapat memilih metode penyusutan yang digunakan untuk masing-masing aset tetap. Jumlah yang disusutkan dikurangkan dari biaya perolehan pada nilai residunya. Beban penyusutan akan diakui dalam laporan laba rugi setiap periodenya, kecuali jika beban tersebut sudah termasuk dalam jumlah tercatat yang lain.

PSAK 69 Agrikultur merupakan standar akuntansi keuangan di Indonesia yang mengatur aset biologis. Standar ini mengacu pada International Accounting Standar (IAS) 41 yang dikeluarkan pada Desember 2000. PSAK 69 disahkan oleh Dewan Standar Akuntansi Keuangan Ikatan Akuntan Indonesia (DSAK IAI) pada 16 Desember 2015 dan diberlakukan secara efektif sejak 1 Januari 2018. Penerapan standar ini sejalan dengan Amandemen PSAK 16 Tanaman Produktif. Ruang lingkup PSAK 69 mencakup aset biologis dan produk agrikultur, sedangkan Bearer Biological Aset (BBA) atau tanaman produktif masuk dalam ruang lingkup PSAK 16 melalui amandemen standar tersebut. PSAK 69 Agrikultur diterapkan untuk pencatatan hal yang berkaitan dengan aktivitas agrikultur. PSAK 69 Agrikultur mengatur mengenai pengakuan, pengukuran, dan pengungkapan hal-hal yang berkaitan dengan aktivitas agrikultur. Aktivitas agrikultur didefinisikan sebagai aktivitas usaha entitas dalam rangka melakukan manajemen transformasi aset biologis untuk mendapatkan produk yang dapat dikonsumsi atau yang memerlukan proses lebih lanjut (Kodriyah \& Monica, 2018). Dalam PSAK 69 Agrikultur dipaparkan beberapa karakteristik umum dari aktivitas agrikultur. Pertama, hewan atau tanaman mempunyai kemampuan untuk berubah (transformasi biologis). Hal ini berdampak pada perubahan aset biologis tersebut. Kedua, manajemen melakukan usaha untuk memfasilitasi proses transformasi biologis dengan memberikan perlakuan yang dapat meningkatkan atau menstabilkan keberlangsungan proses tersebut. Ketiga, manajemen melakukan pengukuran perubahan dalam segi kualitas dan kuantitas. 
PSAK 69 Agrikultur mengatur pengukuran aset biologis didasarkan pada nilai wajar (fair value), bukan pada biaya perolehannya (historical cost). Hal ini dimaksudkan agar nilai aset biologis dapat relevan dengan mencerminkan nilai masa kini. Pengukuran aset biologis menggunakan pendekatan nilai wajar digunakan ketika aset tersebut sesuai dengan kriteria aset biologis yang masuk dalam ruang lingkup PSAK 69. Aset biologis diukur pada nilai wajar dikurangi dengan biaya untuk menjual pada saat pengakuan awal dan setiap akhir periode pelaporan. Keuntungan atau kerugian akibat perubahan nilai wajar aset biologis diakui di laporan rugi laba pada periode terjadinya keuntungan atau kerugian tersebut. Apabila terdapat kondisi dimana aset biologis tidak dapat dinilai secara wajar karena tidak adanya harga kuotasi pasarnya, maka dapat diukur dengan harga perolehannya dikurangi akumulasi penyusutan dan akumulasi kerugian penurunan nilai. Hal lain yang dapat memperbolehkan aset biologis tidak diukur dengan nilai wajar ialah apabila alternatif pengukuran yang berdasarkan nilai wajar tidak secara jelas dapat diandalkan (IAI, 2018).

\section{Metode Penelitian}

Pendekatan kualitatif digunakan dalam penelitian ini untuk mendeskripsikan praktik perlakuan akuntansi di perusahaan agrikultur yang terdaftar di Bursa Efek Indonesia (BEI). Penelitian dengan metode deskriptif komparatif dan interaktif ini bertujuan memberikan gambaran perlakuan akuntansi untuk aset biologis awal mengenai pengakuan, pengukuran, dan pengungkapan aset biologis sebelum dan setelah penerapan PSAK 69. Perbedaan dalam perlakuan akuntansi untuk aset biologis dianalisis berdasarkan PSAK 16 dengan PSAK 69. Pemilihan sampel menggunakan metode purposive sampling, dengan kriteria sebagai berikut: (1) perusahaan sektor agrikultur yang terdaftar di BEI tahun 2017-2018;(2) laporan keuangan tersedia di laman BEI atau laman perusahaan untuk tahun 2017 dan 2018; (3) menggunakan Rupiah sebagai mata uang fungsionalnya serta (4) mencatat aset biologis terpisah dari tanaman produktif (khusus untuk periode 2018).

Dari 21 perusahaan agrikultur terdaftar di BEI, terdapat 15 perusahaan agrikultur yang sesuai dengan kriteria sampel yang ditentukan sebagaimana disajikan pada Tabel 1. Data yang digunakan pada penelitian ini adalah campuran. Data sekunder yang berasal dari laporan keuangan masing-masing perusahaan, sedangkan data primer berasal dari wawancara kepada anggota DSAK IAI.

Tabel 1. Daftar Perusahaan Sampel

\begin{tabular}{clll}
\hline No. & Kode Saham & \multicolumn{1}{c}{ Nama Perusahaan } & \multicolumn{1}{c}{ Tanggal IPO } \\
\hline 1 & BISI & Bisi International Tbk. & 28 Mei 2007 \\
\hline 2 & AALI & Astra Agro Lestari Tbk. & 9 Desember 1997 \\
\hline 3 & BWPT & Eagle High Plantations Tbk. & 27 Oktober 2009 \\
\hline 4 & DSNG & Dharma Satya Nusantara Tbk. & 14 Juni 2013 \\
\hline 5 & GZCO & Gozco Plantations Tbk. & 15 Mei 2008 \\
\hline 6 & JAWA & Jaya Agra Wattie Tbk. & 30 Mei 2011 \\
\hline 7 & LSIP & PP London Sumatera Indonesia Tbk. & 5 Juli 1996 \\
\hline 8 & MAGP & Multi Agro Gemilang Plantation Tbk. & 16 Januari 2013 \\
\hline 9 & PALM & Provident Agro Tbk. & 8 Oktober 2012 \\
\hline 10 & SGRO & Sampoerna Agro Tbk. & 18 Juni 2007 \\
\hline 11 & SIMP & Salim Ivomas Pratama Tbk. & 9 Juni 2011 \\
\hline 12 & SMAR & SMART Tbk. & 20 November 1992 \\
\hline & & &
\end{tabular}




\begin{tabular}{clll}
\hline No. & Kode Saham & \multicolumn{1}{c}{ Nama Perusahaan } & \multicolumn{1}{c}{ Tanggal IPO } \\
\hline 13 & SSMS & Sawit Sumbermas Sarana Tbk. & 12 Desember 2013 \\
\hline 14 & TBLA & Tunas Baru Lampung Tbk. & 14 Februari 2000 \\
\hline 15 & UNSP & Bakrie Sumatera Plantations Tbk. & 6 Maret 1990 \\
\hline
\end{tabular}

Sumber: IDX, data diolah peneliti, 2020

\section{Hasil dan Pembahasan}

Sesuai dengan tujuan penelitian, pada bagian hasil dan pembahasan dideskripsikan perbedaan perlakuan akuntansi aset biologis berdasarkan PSAK 16 dan PSAK 69 pada perusahaan agrikultur dengan fokus pada aspek pengakuan, pengukuran dan pengungkapan serta penerapan PSAK 69 pada perusahaan agrikultur. Sebelum adanya PSAK 69, aset biologis pada perusahaan agrikultur di Indonesia diakui sebagai aset tetap, sehingga perlakuannya menggunakan PSAK 16. Secara umum, PSAK 16 mengakui aset tetap sebagai aset yang digunakan dalam proses pengadaan barang/jasa selama lebih dari satu periode dan memberikan manfaat ekonomis masa depan kepada entitas yang mengendalikannya. Dalam praktik pengakuannya, perusahaan mendeskripsikan karakteristik aset yang masuk dalam kategori aset tetap. Meskipun berpedoman pada PSAK yang sama, karakteristik aset tetap satu perusahaan dengan perusahaan yang lain berbeda. Ada beberapa perusahaan yang menambahkan karakteristik khusus yang hanya ada pada perusahaan tersebut. Hasil analisis tentang pengakuan aset biologis berdasarkan PSAK 16 pada 15 perusahaan agrikultur, dapat dideskripsikan sebagai berikut.

a) Seluruh perusahaan agrikultur mengakui aset biologis sebagai aset, kecuali BISI yang mengakui aset biologisnya sebagai persediaan. Hal ini disebabkan oleh perbedaan jenis aset biologis yang dimiliki. Sebanyak 14 perusahaan agrikultur memiliki aset biologis berupa tanaman perkebunan yang berfungsi sebagai aset untuk memproduksi aset biologis lainnya, sehingga memenuhi kriteria pengakuan aset tetap. Namun demikian, aset biologis yang dimiliki BISI berupa benih jagung, benih sayuran, dan benih padi, yang masa panennya kurang dari satu periode pelaporan. Hal ini tidak sesuai dengan kriteria pengakuan aset tetap, sehingga BISI mengakui aset biologisnya sebagai persediaan dalam proses.

Tabel 2. Batasan Umur Tanaman Kelapa Sawit Dewasa

\begin{tabular}{lc}
\hline \multicolumn{1}{c}{ Nama Perusahaan } & $\begin{array}{c}\text { Umur Dewasa } \\
\text { Tanaman Kelapa Sawit }\end{array}$ \\
\hline Dharma Satya Nusantara Tbk. & 3 tahun \\
Astra Agro Lestari Tbk. & $3-4$ tahun \\
London Sumatera Indonesia Tbk. & $3-4$ tahun \\
Multi Agro Gemilang Plantation Tbk. & $3-4$ tahun \\
Provident Agro Tbk. & $3-4$ tahun \\
Sinar Mas Agro Resources and Technology Tbk. & $3-4$ tahun \\
Sawit Sumbermas Sarana Tbk. & $3-4$ tahun \\
Eagle High Plantations Tbk. & 4 tahun \\
Jaya Agra Wattie Tbk. & 4 tahun \\
Sampoerna Agro Tbk. & 4 tahun \\
Salim Ivomas Pratama Tbk. & 4 tahun \\
Gozco Plantations Tbk. & 5 tahun \\
\hline \multicolumn{1}{c}{ Sumber: Data Penelitian (2020). }
\end{tabular}

Sumber: Data Penelitian (2020). 
b) Setiap perusahaan memiliki kriteria masing-masing dalam mengakui dan mengelompokkan aset biologisnya. Kriteria dalam mengelompokkan aset biologis sangat bergantung pada bagaimana pertimbangan dan penilaian manajemen. Misalnya, pada perusahaan yang memiliki tanaman kelapa sawit, tiap perusahaan memiliki batas umur yang berbeda-beda untuk mengklasifikasikan tanaman kelapa sawit belum menghasilkan menjadi tanaman menghasilkan. Tabel 2 tersebut menjelaskan perbedaan batasan umur dalam mengklasifikasikan umur tanaman kelapa sawit. Tanaman kelapa sawit dinyatakan menjadi tanaman menghasilkan (tanaman dewasa) apabila telah mempunyai tandan buah segar (TBS). Perbedaan umur dewasa ini disebabkan oleh perbedaan aktivitas manajemen agrikultur pada tiap perusahaan. Manajemen agrikultur merupakan aktivitas yang dilakukan perusahaan dalam rangka menciptakan kondisi yang baik untuk mendukung pertumbuhan aset biologis. Perusahaan yang menetapkan tanaman kelapa sawit sebagai tanaman menghasilkan pada umur 3 tahun mungkin melakukan upaya yang lebih efektif dalam proses pengembangan tanaman jika dibandingkan dengan perusahaan lain yang memiliki jangka waktu tanam lebih lama. Hal ini berlaku bagi jenis aset biologis yang lainnya.

Hasil analisis berdasarkan deskripsi pengukuran aset biologis di perusahaan agrikultur periode 2017 , berikut ini beberapa hal yang menjadi perbedaan:

a) BISI mengukur aset biologis miliknya menggunakan nilai yang lebih rendah antara biaya perolehan atau nilai realisasi neto. Hal ini disebabkan oleh jenis aset biologis yang dimiliki seperti benih jagung, benih sayuran, dan benih padi, dimana kriterianya tidak sesuai dengan PSAK 16 yang mengatur aset biologis saat itu. Namun demikian, 14 perusahaan agrikultur lainnya mengukur aset biologis menggunakan biaya perolehan dikurangi akumulasi penyusutan dan akumulasi rugi penurunan nilai.

b) Perusahaan agrikultur menetapkan umur manfaat aset biologisnya berdasarkan penilaian manajemen masing-masing. Jenis aset biologis yang sama bisa saja memiliki umur manfaat yang berbeda di beberapa perusahaan agrikultur. Contohnya, tanaman kelapa sawit pada perusahaan AALI, BWPT, DSNG, GZCO, MAGP, dan SGRO memiliki umur manfaat selama 20 tahun. Namun demikian, tanaman kelapa sawit milik JAWA, LSIP, SIMP, SMAR, dan TBLA memiliki masa manfaat selama 25 tahun. SSMS dan UNSP menilai umur manfaat dari tanaman kelapa sawitnya selama 20 hingga 30 tahun. PALM tidak menilai umur manfaat tanaman kelapa sawitnya karena manajemen tidak menyusutkan aset biologis.

Berkaitan dengan pengungkapan aset biologis perusahaan agrikultur periode 2017, dapat dinyatakan beberapa hal sebagai berikut:

a) BISI mengakui aset biologis sebagai persediaan, sehingga pengungkapannya pun disesuaikan dengan PSAK 14. Berbeda dengan 14 perusahaan agrikultur lainnya yang mengungkapkan beberapa hal mengenai aset biologisnya sesuai dengan PSAK 16.

b) Perusahaan agrikultur menyampaikan mutasi dari aset biologis yang dimilikinya. Mutasi tersebut berisi saldo awal aset biologis, penambahan/ pengurangan selama periode, reklasifikasi (jika ada), dan saldo akhir. Pengungkapan tersebut penting sebagai informasi yang melengkapi laporan neraca yang disajikan. Selain mutasi aset 
biologis, perusahaan yang menggunakan model revaluasi dalam pengukuran setelah pengakuan juga wajib mencantumkan informasi tambahan, seperti tanggal efektif revaluasi, apakah ada keterlibatan jasa penilai independen saat revaluasi, surplus revaluasi, dan nilai aset biologis apabila aset diukur dengan model biaya.

Sejak disahkannya PSAK 69, akuntansi untuk aktivitas agrikultur secara utuh diatur perlakuannya dalam PSAK 69 tersebut. Hal ini merupakan angin segar bagi para pelaku usaha di sektor agrikultur. Selama ini, perusahaan agrikultur menggunakan standar lain yang tentu saja tidak memerhatikan detail karakteristik dari aset biologis. Aset biologis mengalami transformasi biologis, sedangkan standar sebelumnya tidak menyinggung karakteristik itu sama sekali. Dengan adanya PSAK 69 yang mengatur agrikultur ini, perusahaan dapat menyajikan laporan keuangan yang lebih relevan. Aset biologis yang dibahas dalam pemaparan perlakuan akuntansi berdasarkan PSAK 69 ini merupakan aset biologis yang secara jelas diakui sebagai aset biologis perusahaan. Peneliti berasumsi entitas yang dibahas telah menerapkan PSAK 69 secara utuh. Dari pemaparan mengenai deskripsi pengakuan aset biologis pada 15 perusahaan agrikultur periode 2018 dapat diuraikan beberapa hal sebagai berikut:

a) Seluruh perusahaan agrikultur mengakui aset biologis sebagai aset. Namun, MAGP tidak mencatatkan aset biologisnya ke dalam laporan keuangan konsolidasian dikarenakan nilainya yang dianggap tidak material.

b) Perusahaan agrikultur mencatat aset biologis berupa produk agrikultur dan tanaman semusim sebagai aset lancar, sedangkan aset hewan dicatat sebagai aset tidak lancar.

Dari aspek pengukuran aset biologis pada perusahaan agrikultur tersebut dapat dideskripsikan bahwa:

a) Sebanyak 14 perusahaan agrikultur yang dapat mengukur nilai wajar aset biologisnya secara andal telah menerapkan pengukuran dengan nilai wajar dikurangi biaya untuk menjual. BISI mengukur aset biologisnya menggunakan biaya perolehan dikurangi akumulasi penyusutan dan akumulasi penurunan nilai. Nilai wajar dari aset biologis yang dimilikinya tidak dapat diukur secara andal karena sifat aset biologis milik BISI tidak sesuai dengan produk yang diperjualbelikan di pasar.

b) Terdapat perbedaan pada cara pengukuran nilai wajarnya. Ada beberapa perusahaan agrikultur yang mengestimasi volume produksi, ada juga yang menggunakan pendekatan pendapatan. Hal ini dikarenakan tidak adanya harga kuotasian untuk produk agrikultur, sehingga perusahaan mengestimasi sesuai dengan ketentuannya masing-masing.

Berdasarkan pengungkapan aset biologis pada perusahaan agrikultur periode 2018 dapat dinyatakan bahwa beberapa hal sebagai berikut:

a) BISI mengungkapkan alasan mengenai penggunaan biaya perolehan dalam mengukur aset biologisnya.

b) MAGP tidak mengungkapkan mutasi dari aset biologisnya.

c) Perusahaan agrikultur lainnya mengungkapkan jumlah aset biologis pada awal dan akhir periode. 
Perlakuan akuntansi aset biologis berdasarkan PSAK 16 dan PSAK 69 memiliki perbedaan dikarenakan rincian perlakuan yang berbeda. PSAK 69 yang secara khusus mengatur akuntansi untuk aktivitas agrikultur memperlakukan aset biologis dengan lebih jelas. Karakteristik aset biologis, yaitu transformasi biologis juga diperhatikan dalam tiap butir perlakuannya. Contoh perlakuan akuntansi aset biologis yang terpengaruh oleh transformasi biologis ialah produk agrikultur, sebagai hasil produksi (produce) tanaman menghasilkan dicatat terpisah dari tanaman produktifnya. Namun demikian, PSAK 16 yang tidak secara detail memperhatikan poin transformasi biologis pada aset biologis tentu saja tidak memisahkan pencatatan produk agrikulturnya. Hal ini sangat wajar mengingat PSAK 16 merupakan standar yang digunakan untuk aset tetap secara umum, tidak ditujukan hanya untuk satu jenis aset tetap. Dari hasil analisis mengenai perlakuan akuntansi aset biologis berdasarkan PSAK 16 dan PSAK 69 di perusahaan agrikultur dapat diidentifikasi beberapa perbedaan sebagai berikut:

1) Perbedaan pengakuan aset biologis berdasarkan PSAK 16 dan PSAK 69 di perusahaan agrikultur terdapat pada ruang lingkup pengakuan. Perusahaan agrikultur mengakui tanaman perkebunan sebagai aset dan tidak mengakui produk agrikultur sebagai aset biologis berdasarkan PSAK 16. Namun demikian, berdasarkan PSAK 69, perusahaan agrikultur tidak mengakui tanaman perkebunan sebagai aset biologis, melainkan sebagai aset tetap. Aset biologis yang diakui oleh perusahaan agrikultur berupa produk agrikultur, tanaman semusim, dan hewan. Perusahaan agrikultur awalnya mengakui aset biologis sebagai aset tidak lancar, setelah penerapan PSAK 69, perusahaan agrikultur mengakui aset biologis sebagai aset lancar dan aset tidak lancar.

2) Pengukuran aset biologis berdasarkan PSAK 16 di perusahaan agrikultur menggunakan biaya perolehan dengan rincian biaya kapitalisasi yang berbeda-beda tiap perusahaannya, kecuali BISI yang menggunakan pengukuran nilai persediaan, yaitu nilai yang lebih rendah antara biaya perolehan atau nilai realisasi neto. Aset biologis juga masih mengalami penyusutan, kecuali pada PALM. PSAK 69 mengukur aset biologis perusahaan agrikultur menggunakan nilai wajar dikurangi biaya untuk menjual, kecuali BISI yang nilai wajarnya tidak dapat diukur secara andal. Aset biologis tidak disusutkan.

3) Pada pengungkapan mengenai aset biologis di perusahaan agrikultur berdasarkan PSAK 16 terdapat poin penyusutan, berupa umur manfaat, tarif penyusutan, dan metode yang digunakan. Berdasarkan PSAK 69, perusahaan agrikultur mengungkapkan deskripsi kelompok aset biologis dan nilai keuntungan/ kerugian yang timbul akibat penggunaan nilai wajar.

Dengan menggunakan kriteria penerapan PSAK 69 yang ada pada Tabel 3, peneliti menganalisis penerapan PSAK 69 pada perusahaan agrikultur. Analisis dilakukan dengan cara mencari dan menelaah poin-poin pengungkapan yang ada di laporan tahunan (annual report) yang dipublikasikan oleh perusahaan agrikultur berdasarkan kriteria penerapan yang digunakan untuk menilai penerapan PSAK 69 sebagaimana disajikan pada Tabel 3. Analisis penerapan PSAK 69 yang dilakukan peneliti berfokus pada perlakuan akuntansi yang dapat ditelaah dari laporan tahunan perusahaan agrikultur yang dianalisis. 
Tabel 3. Kriteria Penerapan Perlakuan Akuntansi Berdasarkan PSAK 69

\begin{tabular}{|c|c|c|}
\hline No. & Aspek & Deskripsi \\
\hline 1 & $\begin{array}{l}\text { Pengakuan \& } \\
\text { Pengukuran }\end{array}$ & Perusahaan mengendalikan aset biologis sebagai akibat dari peristiwa masa lalu. \\
\hline 2 & & $\begin{array}{l}\text { Besar kemungkinan manfaat ekonomik masa depan yang terkait dengan aset } \\
\text { biologis tersebut akan mengalir ke perusahaan. }\end{array}$ \\
\hline 3 & & Nilai wajar atau biaya perolehan dari aset biologis dapat diukur secara andal. \\
\hline 4 & & $\begin{array}{l}\text { Perusahaan mengukur aset biologis pada nilai wajar dikurangi biaya untuk } \\
\text { menjual. } \\
\text { Jika nilai wajar tidak dapat diukur secara andal, aset biologis dapat diukur pada } \\
\text { biaya perolehannya dikurangi akumulasi penyusutan dan akumulasi kerugian } \\
\text { penurunan nilai pada saat pengakuan awal saja. }\end{array}$ \\
\hline 5 & & $\begin{array}{l}\text { Perusahaan mengukur nilai wajar dikurangi biaya untuk menjual aset biologis } \\
\text { pada saat pengakuan awal dan tiap akhir periode. } \\
\text { Jika saat pengakuan awal nilai wajar tidak dapat diukur secara andal, perusahaan } \\
\text { melanjutkan mengukur aset biologis pada nilai wajar setelah dikurangi biaya } \\
\text { untuk menjual sampai pada saat pelepasan. } \\
\text { Jika selama periode berjalan perusahaan mengukur aset biologisnya pada biaya } \\
\text { perolehan dikurangi akumulasi penyusutan/kerugian penurunan nilai, maka } \\
\text { perusahaan mengungkapkan keuntungan/kerugian yang diakui atas pelepasan } \\
\text { aset biologis tersebut dan rekonsiliasi yang mencakup kerugian penurunan nilai, } \\
\text { pembalikan rugi penurunan nilai \& penyusutan. }\end{array}$ \\
\hline 6 & & $\begin{array}{l}\text { Perusahaan tidak memperhitungkan arus kas untuk pembiayaan aset, perpajakan, } \\
\text { atau penumbuhan kembali aset biologis setelah panen. }\end{array}$ \\
\hline 7 & Pengungkapan & $\begin{array}{l}\text { Untuk perusahaan yang nilai wajar aset biologisnya dapat diukur secara andal: } \\
\text { Perusahaan menyajikan keuntungan atau kerugian yang timbul pada saat } \\
\text { pengakuan awal aset biologis pada nilai wajar dikurangi biaya untuk menjual } \\
\text { dan dari perubahan nilai wajar dikurangi biaya untuk menjual aset biologis } \\
\text { dimasukkan dalam laba rugi periode saat keuntungan atau kerugian tersebut } \\
\text { terjadi. } \\
\text { Untuk perusahaan yang nilai wajar aset biologisnya tidak dapat diukur secara } \\
\text { andal: } \\
\text { Jika perusahaan mengukur aset biologis pada biaya perolehan dikurangi } \\
\text { akumulasi penyusutan dan akumulasi kerugian penurunan nilai pada akhir } \\
\text { periode, maka perusahaan mengungkapkan deskripsi aset biologis tersebut, } \\
\text { penjelasan tentang mengapa alasan nilai wajar tidak dapat diukur secara andal, } \\
\text { rentang estimasi dimana nilai wajar kemungkinan besar berada (jika } \\
\text { memungkinkan), metode penyusutan, umur manfaat dan tarif penyusutan, dan } \\
\text { jumlah tercatat bruto dan akumulasi penyusutan. } \\
\text { Jika selama periode nilai wajar menjadi dapat diukur secara andal, maka } \\
\text { perusahaan mengungkapkan deskripsi dari aset biologis tersebut, penjelasan } \\
\text { tentang mengapa nilai wajar dapat diukur secara andal, dan dampak dari } \\
\text { perubahan tersebut. }\end{array}$ \\
\hline 8 & & Perusahaan mendeskripsikan setiap kelompok aset biologis. \\
\hline 9 & & $\begin{array}{l}\text { Perusahaan membedakan aset biologis yang dapat dikonsumsi dan aset biologis } \\
\text { produktif. }\end{array}$ \\
\hline 10 & & $\begin{array}{l}\text { Perusahaan mendeskripsikan sifat aktivitasnya yang melibatkan kelompok aset } \\
\text { biologis. }\end{array}$ \\
\hline 11 & & $\begin{array}{l}\text { Perusahaan mendeskripsikan ukuran dan estimasi nonkeuangan dari kuantitas } \\
\text { fisik: } \\
\text { Setiap kelompok aset biologis milik perusahaan pada akhir periode. } \\
\text { Output produk agrikultur selama periode tersebut. }\end{array}$ \\
\hline
\end{tabular}




\begin{tabular}{|c|c|c|}
\hline No. & Aspek & Deskripsi \\
\hline 12 & & $\begin{array}{l}\text { Perusahaan mengungkapkan keberadaan \& jumlah tercatat aset biologis yang } \\
\text { kepemilikannya dibatasi, \& jumlah tercatat aset biologis yang dijaminkan untuk } \\
\text { liabilitas. }\end{array}$ \\
\hline 13 & & $\begin{array}{l}\text { Perusahaan mengungkapkan jumlah komitmen untuk pengembangan/akuisisi } \\
\text { aset biologis. }\end{array}$ \\
\hline 14 & & $\begin{array}{l}\text { Perusahaan mengungkapkan strategi manajemen risiko keuangan yang terkait } \\
\text { dengan aktivitas agrikultur. }\end{array}$ \\
\hline 15 & & $\begin{array}{l}\text { Perusahaan menyajikan rekonsiliasi jumlah tercatat aset biologis antara awal dan } \\
\text { akhir periode berjalan. }\end{array}$ \\
\hline 16 & & $\begin{array}{l}\text { Perusahaan mengungkapkan, berdasarkan kelompok atau lainnya, jumlah } \\
\text { perubahan nilai wajar dikurangi biaya untuk menjual yang termasuk dalam laba } \\
\text { rugi akibat perubahan fisik atau perubahan harga. }\end{array}$ \\
\hline
\end{tabular}

Sumber: PSAK 69 (2020)

Tingkat penerapan PSAK 69 dihitung dengan cara membandingkan jumlah item kriteria penerapan yang terpenuhi dengan total item kriteria penerapan pada tabel 3. Dari hasil analisis penerapan PSAK 69, peneliti ini dapat memetakan perusahaan agrikultur yang telah sepenuhnya menerapkan PSAK 69 dan mana yang belum. Dalam tabel 4, diketahui bahwa seluruh perusahaan agrikultur yang dijadikan sebagai sampel telah menerapkan PSAK 69 lebih dari atau sama dengan 50\%. Pada kategori tingkat penerapan PSAK 69 kurang dari 100\%, ada 12 perusahaan yang masuk dalam kategori ini, yaitu BISI, AALI,DSNG, GZCO, JAWA, MAGP, PALM, SIMP, SMAR, SSMS, TBLA, dan UNSPD.

Tabel 4. Tingkat Penerapan PSAK 69 pada Perusahaan Agrikultur Tahun 2018

\begin{tabular}{lccc}
\hline $\begin{array}{c}\text { Kode } \\
\text { Perusahaan }\end{array}$ & $\begin{array}{c}\text { Jumlah Item Indikator } \\
\text { Terpenuhi }\end{array}$ & $\begin{array}{c}\text { Total Item } \\
\text { Indikator }\end{array}$ & Tingkat Penerapan \\
\hline BISI & 10 & 16 & $63 \%$ \\
\hline AALI & 13 & 16 & $81 \%$ \\
\hline BWPT & 16 & 16 & $100 \%$ \\
\hline DSNG & 15 & 16 & $94 \%$ \\
\hline GZCO & 12 & 16 & $75 \%$ \\
\hline JAWA & 14 & 16 & $88 \%$ \\
\hline LSIP & 16 & 16 & $100 \%$ \\
\hline MAGP & 8 & 16 & $50 \%$ \\
\hline PALM & 14 & 16 & $88 \%$ \\
\hline SGRO & 16 & 16 & $100 \%$ \\
\hline SIMP & 15 & 16 & $94 \%$ \\
\hline SMAR & 14 & 16 & $88 \%$ \\
\hline SSMS & 15 & 16 & $94 \%$ \\
\hline TBLA & 13 & 16 & $81 \%$ \\
\hline UNSP & 15 & 16 & $94 \%$ \\
\hline SUmber: & & &
\end{tabular}

Sumber: Data diolah, 2020

BISI merupakan salah satu perusahaan agrikultur yang aset biologisnya merupakan tanaman semusim (annual crops) yang tidak dapat diukur nilai wajarnya. Hal ini berdampak pada pengungkapannya lebih sedikit dibanding yang lainnya. Misalnya, 
pengungkapan jumlah perubahan nilai wajar dikurangi biaya untuk menjual saat pengakuan awal hingga akhir periode dianggap tidak material sehingga ditiadakan. BISI juga tidak mendeskripsikan tiap-tiap kelompok aset biologisnya dan sifat aktivitas yang melibatkan aset biologisnya. Keberadaan dan jumlah tercatat aset biologis yang kepemilikiannya dibatasi dan jumlah komitmen perusahaan untuk mengembangkan atau mengakuisisi aset biologis juga tidak diungkapkan. Selain itu, BISI tidak mengungkapkan jumlah perubahan nilai wajar dikurangi biaya untuk menjual. Hal tersebut dikarenakan tanaman semusim tidak mengalami perubahan yang signifikan dalam satu siklusnya.

JAWA, PALM, dan SMAR menerapkan 14 dari total 16 poin dalam kriteria penerapan PSAK 69. Manajemen JAWA dan SMAR sama-sama tidak mengungkapkan mengenai jumlah komitmen yang digunakan perusahaan dalam pengembangan/ akuisisi aset biologisnya dan strategi manajemen resiko keuangan yang terkait dengan aktivitas agrikulturnya. PALM tidak mengungkapkan keberadaan dan jumlah tercatat aset biologis yang kepemilikannya dibatasi, dan jumlah tercatat aset biologis yang dijaminkan untuk liabilitas, serta jumlah komitmen yang digunakan dalam pengembangan/ akuisisi aset biologisnya. DSNG, SIMP, dan SSMS memiliki tingkat penerapan 94\%, dimana hanya ada satu poin yang belum sesuai dengan PSAK 69. DSNG tidak mengungkapkan strategi manajemen resiko keuangan yang ada kaitannya dengan aktivitas agrikultur. SIMP tidak mengungkapkan keberadaan dan jumlah tercatat aset biologis yang kepemilikannya dibatasi, dan jumlah tercatat aset biologis yang dijaminkan untuk liabilitas. SSMS tidak mengungkapkan jumlah komitmen yang digunakan dalam pengembangan/ akuisisi aset biologis miliknya. BWPT, LSIP, dan SGRO merupakan tiga perusahaan agrikultur yang memiliki tingkat penerapan PSAK 69 sebesar 100\%. Berdasarkan analisis, ketiga perusahaan ini menerapkan PSAK 69 secara utuh karena telah memenuhi seluruh kriteria penerapan yang ada di tabel 3. Ringkasan pemetaan tingkat penerapan PSAK 69 pada perusahaan agrikultur disajikan pada Tabel 5.

Tabel 5. Pemetaan Tingkat Penerapan PSAK 69 pada Perusahaan Agrikultur

\begin{tabular}{ccl}
\hline $\begin{array}{c}\text { Tingkat Penerapan } \\
\text { PSAK 69 }\end{array}$ & $\begin{array}{c}\text { Jumlah } \\
\text { Perusahaan }\end{array}$ & Kode Perusahaan \\
\hline$<100 \%$ & 12 & $\begin{array}{l}\text { BISI, AALI, DSNG, GZCO, JAWA, MAGP, PALM, } \\
\text { SIMP, SMAR, SSMS, TBLA, UNSP }\end{array}$ \\
\hline $100 \%$ & 3 & BWPT, LSIP, SGRO \\
\hline
\end{tabular}

Sumber: Data Penelitian (diolah), Tahun 2020

Penerapan PSAK 69 di perusahaan agrikultur menimbulkan perubahan penyajian aset biologis. Perubahan pengakuan aset biologis akan berpengaruh terhadap laporan posisi keuangan. Perubahan pengukuran akan menimbulkan adanya keuntungan/ kerugian atas penggunaan nilai wajar dikurangi biaya menjual, sehingga akan dicatat dalam laporan laba rugi. Pada pengakuan aset biologis, sebelum penerapan PSAK 69, produk agrikultur tidak dipisahkan dengan tanaman produktif, tanaman semusim dicatat sebagai persediaan, dan aset hewan mengalami depresiasi. Hal tersebut berdampak pada jumlah aset tercatat. Misalnya, TBS yang merupakan produk agrikultur dari tanaman kelapa sawit pada awalnya tidak diukur terpisah. Namun, sejak diterapkannya PSAK 69, perusahaan mencatat nilai TBS terpisah dari tanaman produktifnya. 
Peneliti menggunakan AALI sebagai salah satu contoh perusahaan yang pada periode 2017 tidak memisahkan aset biologis dan pada periode 2018 sudah memisahkan aset biologis. Pada Tabel 6 tersedia rincian nilai aset biologis yang dimiliki oleh AALI untuk periode 2017 dan 2018. Pada periode 2017, AALI mencatatkan sebagian aset hewan sebagai salah satu komponen persediaan dengan nilai tercatat sebesar Rp 24.909.000.000,00. Aset hewan indukan/ hewan perah masuk dalam kategori aset lancar dengan nilai $\mathrm{Rp}$ 132.923.000.000,00. AALI tidak memisahkan pencatatan produk agrikultur tanaman kelapa sawitnya, sedangkan periode 2018, AALI sudah memisahkan akun aset biologis, dimana terdapat komponen aset hewan dan produk agrikulturnya.

Tabel 6. Nilai Tercatat Aset Biologis AALI (dalam jutaan Rupiah)

\begin{tabular}{lrlrr}
\hline \multicolumn{1}{c}{2017} & & \multicolumn{2}{c}{2018} & $\begin{array}{c}\text { Jumlah Aset Biologis } \\
\text { Periode 2017 Setelah } \\
\text { Penyajian Kembali }\end{array}$ \\
\hline Aset Hewan (Persediaan) & 24.909 & Aset Biologis (Aset Lancar) & 174.827 & 259.627 \\
\hline TM & 5.154 .777 & TM & 5.681 .689 & 5.154 .777 \\
\hline TBM & 1.592 .437 & TBM & 1.367 .116 & 1.592 .437 \\
\hline $\begin{array}{l}\text { Aset Hewan (Aset Tidak } \\
\text { Lancar) }\end{array}$ & 132.923 & $\begin{array}{l}\text { Aset Biologis (Aset Tidak } \\
\text { Lancar) }\end{array}$ & 149.489 & 132.923 \\
\hline Total Aset Biologis & 6.905 .046 & Total Aset Biologis & 7.373 .121 & 7.139 .764 \\
\hline
\end{tabular}

Sumber: Annual Report AALI 2017 dan 2018, Data diolah peneliti, 2020

Total aset biologis AALI periode 2017 lebih rendah daripada total aset biologis periode yang sama setelah penyajian kembali. Hal ini disebabkan oleh perbedaan metode pengukuran yang digunakan. Pada periode 2017, aset biologis diukur berdasarkan nilai perolehannya, sedangkan aset biologis periode 2017 setelah penyajian kembali diukur dengan nilai wajar dikurangi biaya untuk menjual sesuai dengan penerapan PSAK 69. Selain karena adanya perbedaan pengukuran, perbedaan jumlah tercatat aset biologis tersebut juga dikarenakan adanya pengakuan terhadap produk agrikultur. Pada laporan keuangan periode 2017, tidak diakui adanya produk agrikultur. Namun demikian, pada laporan keuangan periode 2017 setelah penyajian kembali, produk agrikultur sudah diakui dan diukur secara andal.

Hasil penelitian ini memberikan implikasi teoritis dan implikasi praktis. Implikasi teoritis penelitian ini dapat menggambarkan serta menganalisis perbedaan pada perlakuan akuntansi, terutama aspek pengakuan, pengukuran, dan pengungkapan terhadap aset biologis terutama pada perusahaan agrikultur. Penelitian ini dapat menambah literasi mengenai akuntansi agrikultur. Dalam aspek praktis hasil penelitian ini dapat digunakan oleh perusahaan agrikultur yang terdaftar di Bursa Efek Indonesia sebagai pertimbangan dalam evaluasi penerapan PSAK 69. Evaluasi penerapan PSAK 69 masih sangat mungkin dilakukan karena periode penerapannya yang saat ini baru memasuki periode ke-3. Perusahaan perlu mengevaluasi kembali penerapan standar-standar yang digunakan agar laporan keuangan yang disajikan dapat dibandingkan secara global. Secara spesifik, dalam perlakuan akuntansi aset biologis, perusahaan agrikultur diharapkan dapat mendeskripsikan pengelompokkan aset biologis berdasarkan atribut signifikannya, berupa umur atau kualitas agar memudahkan penentuan nilai wajar aset biologis. Perusahaan dapat 
menentukan pendekatan yang tepat dalam menentukan nilai wajar aset biologis. Penggunaan nilai wajar dikurangi biaya untuk menjual dalam mengukur aset biologis dapat meningkatkan nilai aset perusahaan.

\section{Kesimpulan, Implikasi dan Keterbatasan}

Perlakuan akuntansi untuk aset biologis berdasarkan PSAK 16 dan PSAK 69 pada perusahaan agrikultur terdapat beberapa perbedaan, baik dari aspek pengakuan, pengukuran maupun pengungkapan. Berdasarkan PSAK 16, perusahaan agrikultur mengakui tanaman perkebunan sebagai aset dan tidak mengakui produk agrikultur sebagai aset biologis, sedangkan berdasarkan PSAK 69, perusahaan agrikultur tidak mengakui tanaman perkebunan sebagai aset biologis, melainkan sebagai aset tetap. Aset biologis yang diakui oleh perusahaan agrikultur berupa produk agrikultur, tanaman semusim, dan hewan. Pengukuran aset biologis pada perusahaan agrikultur berdasarkan PSAK 16 menggunakan biaya perolehan dengan rincian biaya kapitalisasi yang berbeda-beda tiap perusahaannya dan aset biologis mengalami penyusutan, sedangkan PSAK 69 mengukur aset biologis perusahaan agrikultur menggunakan nilai wajar dikurangi biaya untuk menjual dan aset biologisnya tidak disusutkan. Perusahaan agrikultur berdasarkan PSAK 16 mengungkapkan poin penyusutan, berupa umur manfaat, tarif penyusutan, dan metode penyusutan yang digunakan, sedangkan berdasarkan PSAK 69 mengungkapkan deskripsi kelompok aset biologis dan nilai keuntungan/kerugian yang timbul akibat penggunaan nilai wajar. Sebanyak 3 dari 15 perusahaan agrikultur yang terdaftar di Bursa Efek Indonesia periode 2018 telah menerapkan PSAK 69 secara penuh dengan persentase penerapan sebesar $100 \%$, sedangkan 12 perusahaan agrikultur lainnya menerapkan PSAK 69 dengan persentase $50 \%$ hingga $94 \%$.

Implikasi hasil penelitian ini memberikan gambaran tentang adopsi standar perlakuan akuntansi untuk aset biologis dalam praktik di perusahaan agrikultur sebelum dan setelah penerapan PSAK 69. Dalam aspek regulasi hasil penelitian ini dapat memberikan masukan untuk penyempurnaan standar akuntansi yang berkaitan pengakuan, pengukuran dan pengungkapan aset biologis pada perusahaan agrikultur. Penelitian ini memiliki beberapa hal yang menjadi keterbatasan. Penelitian ini menggunakan laporan keuangan tahun 2018 dalam mendeskripsikan perlakuan akuntansi aset biologis di perusahaan agrikultur. Tahun tersebut merupakan periode pertama penerapan PSAK 69, sehingga perusahaan masih dalam tahap penyesuaian akibat penerapan yang memungkinkan terdapat beberapa hal yang tidak diungkapkan karena dianggap tidak material. Analisis penerapan PSAK 69 hanya melalui laporan keuangan, dimana tidak seluruh detail diungkapkan didalamnya. Peneliti ini terbatas hanya menggunakan perusahaan agrikultur sebagai sampel yang dimana bergerak di subsektor perkebunan, sehingga penelitian ini kurang mewakili perusahaan-perusahaan yang asetnya masuk dalam ruang lingkup PSAK 69. 


\section{Daftar Pustaka}

Ariyanto, S., Sukendar, H., \& Kurniawati, H. (2014). Penerapan PSAK Adopsi IAS 41 Agriculture. Binus Business Review, 5(1), 186-193.

Deloitte. (n.d.). IAS 41 - Agriculture. Iasplus.Com. Retrieved March 24, 2020, from https://www.iasplus.com/en/standards/ias/ias41

Feleaga, L., Feleaga, N., \& Raileanu, V. (2012). Theoretical considerations about implementation of IAS 41 in Romania. Theoretical and Applied Economics, XIX(2), $31-38$.

Ghozali, I., \& Chairiri, A. (2007). Teori Akuntansi (3rd ed.). Badan Penerbit Universitas Diponegoro.

Gischa, S. (2019, December 12). Indonesia sebagai Negara Agraris, Apa Artinya? Kompas.Com.

https://www.kompas.com/skola/read/2019/12/12/172322669/indonesia-sebagainegara-agraris-apa-artinya?page $=$ all

Hariyanti, A. I., \& Wijayanti, N. (2018). Analisis Perbandingan Perlakuan Akuntansi Aset Biologis Berdasarkan International Accounting Standard 41 dan Pernyataan Standar Akuntansi Keuangan 69 pada Perusahaan Perkebunan yang Terdaftar di Bursa Efek Indonesia. Prosiding Seminar Nasional Dan Call for Papers "Pengembangan Sumber Daya Perdesaan Dan Kearifan Lokal Berkelanjutan VIII" 14-15 November 2018 Purwokerto, 41(November), 53-63.

IAI. (2018). Standar Akuntansi Keuangan. IAI.

IDX. (2019). Fact Book IDX 2019. IDX. https://www.idx.co.id/data-pasar/laporanstatistik/fact-book/

indonesia.go.id. (2018, November 17). Indonesia, Negara Megabiodiversitas. Indonesia.go.id. $\quad$ https://indonesia.go.id/ragam/keanekaragamanhayati/ekonomi/indonesia-negara-megabiodiversitas

Kodriyah, \& Monica, V. (2018). Perbandingan Asset Biologis Berdasarkan IAS 41 Agriculture dan PSAK 16 Aset Tetap. Management \& Accounting Expose, 1(1), 6371.

Saputra, D., \& Kurniawan. (n.d.). Implementasi Amandemen IAS 41 di Indonesia, Malaysia dan Thailand. 1-15.

Suhartono, S. (2018). Analisis Komparasi Relevansi Nilai Informasi Akuntansi Sebelum dan Sesudah Adopsi Penuh IFRS di Indonesia. Jurnal Akuntansi Bisnis, 11(1), 68-81. https://doi.org/10.30813/jab.v11i1.1084

Syukra, R. (2019). Rakornas Kadin: Investasi Sektor Pertanian Harus Diperkuat. Investor Daily. https://investor.id/business/rakornas-kadin-investasi-sektor-pertanian-harusdiperkuat 